\title{
Modeling of Compressor Performance Deterioration Due to Erosion*
}

\author{
A. HAMED, W. TABAKOFF ${ }^{\dagger}$ and D. SINGH \\ Department of Aerospace Engineering and Engineering Mechanics, University of Cincinnati, Cincinnati, OH 45221, USA
}

(Received 27 February 1997; In final form 7 March 1997)

\begin{abstract}
This paper presents the results of a simulation of compressor performance deterioration due to blade erosion. The simulation at both design and off-design conditions is based on a mean line row by row model, which incorporates the effects of blade roughness and tip clearance. The results indicate a pronounced effect of blade erosion on the compressor adiabatic efficiency and a lesser effect on the pressure ratio. The loss in performance is mainly caused by the increased blade surface roughness and was highest at $100 \%$ speed.
\end{abstract}

Keywords: Compressor, Performance deterioration, Simulation, Erosion, Roughness

\section{INTRODUCTION}

Aircraft engines are often exposed to ingestion of sand or runway gravel, causing the erosion of fan and compressor blades. This leads to increased blade surface roughness and tip clearances with a subsequent degradation in performance [Hamed, Tabakoff and Wenglarz (1988), Tabakoff (1988)]. In addition severe erosion damage can change the blade leading edge characteristics and reduce the blade chord, which can further deteriorate the performance [Balan and Tabakoff (1983, 1984), and Batcho, Moller, Padova and Dunn (1987)].

Several investigators have developed performance deterioration models for compressors based on the "stage stacking" method. In this approach changes were introduced in the individual com- pressor stage characteristics to reflect the effects of erosion [Batcho, Moller, Padova and Dunn (1987), Tabakoff, Lakshminarasimha and Pasin (1990)], and fouling [Muir, Saravanamutto and Marshall (1989), Aker and Saravanamutto (1989)] on the stage pressure, work and efficiency. Using thin airfoil theory, Batcho et al. [1987] modeled the reduction in a compressor stage pressure ratio due to the increased tip clearance and reduced chord caused by erosion, and compared their predictions with experimental results for dust eroded aircraft gas turbine engine. Tabakoff et al. [1990] modified the model by including the effects of increased surface roughness due to erosion and compared their predictions with experimental results in a single stage compressor. The model over predicted the performance deterioration due to erosion. They

* This paper was originally presented at ISROMAC-6.

${ }^{\dagger}$ Corresponding author. 
then applied the model to the multistage J-85 compressor by modifying the individual stage characteristics of Milner et al. (1975) to include the effects of chord reduction due to erosion. The results showed that erosion caused both pressure and mass flow rate to decrease, this reduction was found to be a function of both the compressor speed as well as the location of the stage where erosion occurred.

In general, the individual stage characteristic curves which are required in the "stage stacking" method are not available in the open literature. Therefore in the present investigation, a mean line method was developed to model the effects of erosion on compressor performance. Mean line methods are based on resolution of velocity triangles for each blade row and the application of loss correlations to establish the pressure and temperature rises through the stage [Casey (1987), Miller and Wasdell (1987)]. In the present investigation the effects of increased surface roughness and tip clearance due to erosion are introduced into the loss model. This model could generally be applied to predict the compressor stage performance, given the blade inlet and exit metal angles, blade stagger, camber, chord, solidity, thickness to chord ratio, and hub and tip diameters.

\section{MODEL DESCRIPTION}

The mean line performance model is based on the use of empirical correlation's for the incidence and deviation angles and pressure losses, which are separated into, profile, annulus, secondary and tip clearance losses [Casey (1987), Miller and Wasdell (1987)]. In the present study the NASA SP-36 [Johnsen and Bullock (1965)] correlation is used for incidence angle and Carter's model [Horlock (1973)] is used to calculate the flow deviation angle. The loss model developed by Koch and Smith [Koch and Smith (1976)] is used for design point operation, whereas Swan's method [Swan (1961)] is used for off-design loss predictions. It is assumed that the secondary losses are not affected by erosion and are given by following equation
[Horlock (1973)]:

$$
\omega_{\mathrm{s}}=(0.072 / \sigma)\left(\cos ^{2} \beta_{2} / \cos \beta_{\mathrm{m}}\right)\left(\tan \beta_{2}-\tan \beta_{1}\right)^{2} \text {. }
$$

\section{EFFECT OF INCREASED SURFACE ROUGHNESS}

Balan and Tabakoff [Balan and Tabakoff (1983, 1984)] conducted an experimental study in which they measured compressor cascades and single stage compressor performance after various amounts of sand were ingested. Both the cascade and compressor performance deteriorated with increased sand ingestion. They attributed the loss of performance to the following changes, which were characterized in their reported results:

1. Increased blade surface roughness.

2. Increased blade tip clearance.

3. Blunting of blade leading edges.

4. Thinning of the trailing edge and shortening of the chord.

The experimental results of Balan and Tabakoff (1983, 1984) indicated an initial sharp rise in cascade losses with increased sand mass ingestion up to $0.10 \mathrm{Kg} / \mathrm{cm}^{2}$, then the losses remained practically unchanged up to a sand mass ingestion of $0.32 \mathrm{Kg} / \mathrm{cm}^{2}$, before increasing sharply again. The latter increase in losses was attributed to the blunting of the blade leading edge and shortening of the blade chord. The initial rise in loss coefficient was attributed to the movement of the transition point towards the leading edge, with increased surface roughness. The levels of blade erosion considered in the present investigation are within that range. Two levels of roughness representative of those observed in the experimental work of Balan and Tabakoff (1984) were simulated.

CASE A: Moderate erosion. Rotor and stator surface roughness, $\mathrm{R}_{\mathrm{a}}=4.0 \mu \mathrm{m}$.

CASE B: Higher erosion, with transition point at minimum distance from the leading edge. Rotor roughness, $\mathrm{R}_{\mathrm{a}}=8.0 \mu \mathrm{m}$, stator roughness, $R_{a}=6.0 \mu \mathrm{m}$. 
The following correlation for drag on a fully rough flat plate [Mills and Hang (1983)] was used to model the effects of increased surface roughness in the calculation of the profile losses due to the boundary layer development on the blade surface.

$$
\mathrm{C}_{\mathrm{d}}=\left(2.625-0.618 \log _{\mathrm{e}}\left(\mathrm{k}_{\mathrm{s}} / \mathrm{c}\right)\right)^{-2.57} .
$$

The equivalent sand grain roughness, $\mathrm{k}_{\mathrm{s}}$ was taken to be equal to 6.2 times the center line average roughness [Koch and Smith (1976)], and the center line average surface roughness of smooth blades was taken as $R_{a}=0.371 \mu \mathrm{m}$ [Kramer and Smith (1978)]. The contribution of the surface roughness to the profile loss is calculated from the following relation:

$$
\omega=\mathrm{C}_{\mathrm{d}} \sigma\left(\cos \beta_{1}\right)^{2} /\left(\cos \beta_{\mathrm{m}}\right)^{3} .
$$

\section{EFFECT OF INCREASED TIP CLEARANCE}

The loss in efficiency due to increased tip clearance is modeled using the empirical correlation of Lakshminarayana (1970).

$$
\begin{aligned}
\Delta \eta= & (1.4 \Delta \mathrm{t} \Psi / \mathrm{h}) /\left(\cos \beta_{\mathrm{m}}\right) \\
& \times\left\{1+10\left[(\phi \Delta \mathrm{t} / \mathrm{c}) /\left(2 \Psi \cos \beta_{\mathrm{m}}\right)\right]^{0.5}\right\} .
\end{aligned}
$$

The increase in the rotor tip clearance due to erosion was taken to be equal to $1 \%$ of the blade height based on the experimental data of Balan and Tabakoff (1984).

In the model, the flow conditions at the blade row exit are iterated from the assumption of an initial exit axial velocity and the upgraded loss calculations. The exit conditions of each blade row constitute the input conditions to the next blade row.

\section{RESULTS AND DISCUSSIONS}

The compressor performance simulation were performed for a single stage axial compressor with NACA 65 airfoils. The performance parameters for stage 23B-20 of Britsch et al. (1979) are listed below:

$\begin{array}{ll}\text { Speed } & : 9,170 \mathrm{rpm} \\ \text { Pressure Ratio } & : 1.252 \\ \text { Mass Flow } & : 9.475 \mathrm{~kg} / \mathrm{s} \\ \text { Tip Speed } & : 243.9 \mathrm{~m} / \mathrm{s} \\ \text { Hub-Tip Ratio } & : 0.8 \\ \text { Aspect Ratio } & : 1.0 \\ \text { Rotor Diffusion Factor }: & 0.44\end{array}$

Figures 1 and 2 compare the computed results for smooth blades at three different speeds ( $\mathrm{N}=100 \%, 90 \%$ and $70 \%$ (design speed)), to the

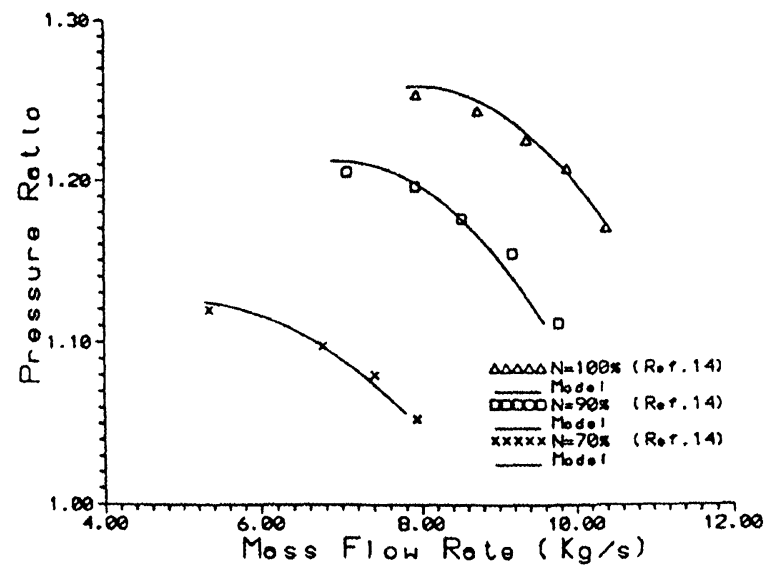

FIGURE 1 Comparison of predicted pressure ratio with actual test results.

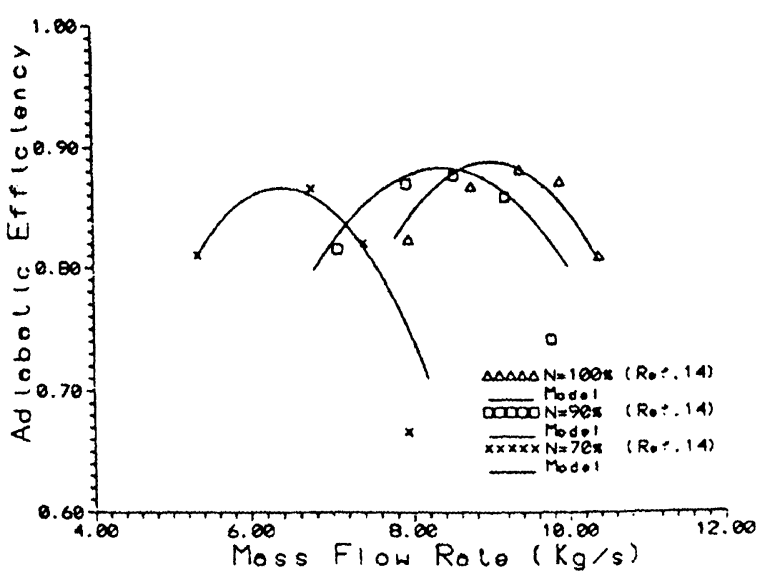

FIGURE 2 Comparison of predicted adiabatic efficiency with actual test results. 
experimental values. The qualitative agreement between the model and the experimental values is quite good at all speeds.

Figure 3 shows the effects of increasing blade surface roughness on the stage pressure ratio. The model predicts a small drop in the pressure ratio at $100 \%$ and $90 \%$ speeds that diminishes at $70 \%$ speed. Figures 4 and 5 are expanded views of the pressure ratio plotted against the mass flow rate for $100 \%$ and $90 \%$ speeds. As seen in both these figures the loss in pressure ratio increases with increased mass flow and can reach $0.5 \%$ in the case of surface roughness corresponding to moderate erosion (case A). Figures 6 and 7 present the effect of surface roughness on adiabatic efficiency. One can see that the roughess has a far greater effect on

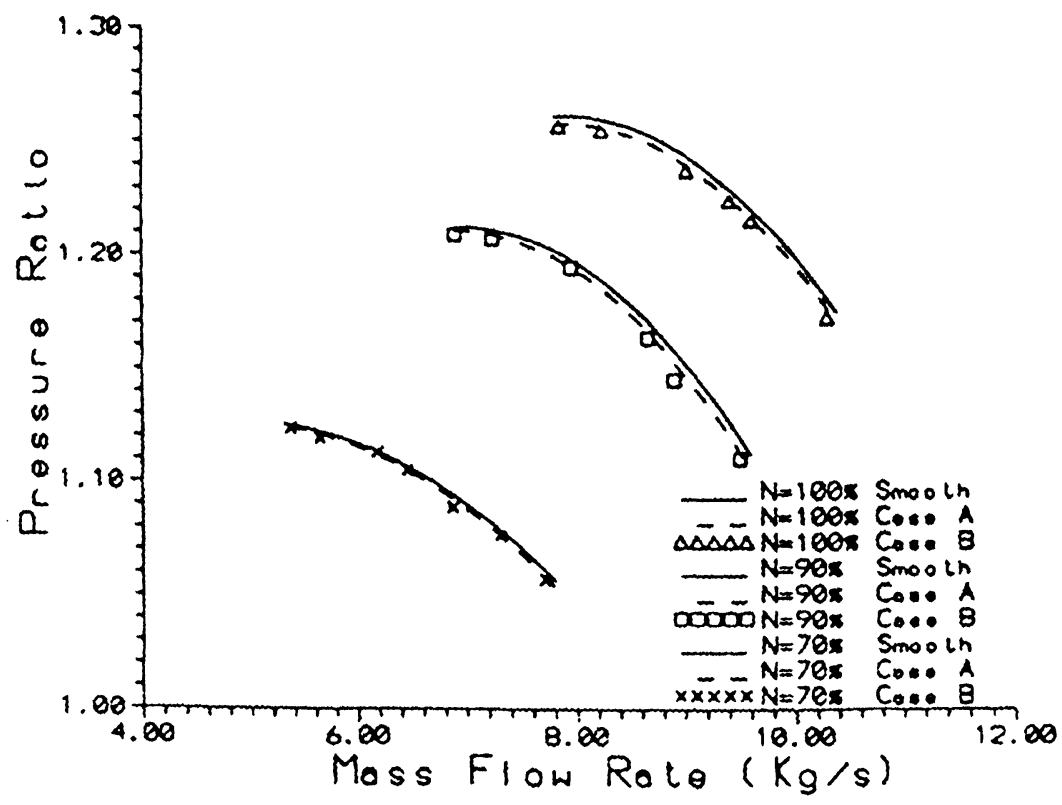

FIGURE 3 Effect of surface roughness on pressure ratio.

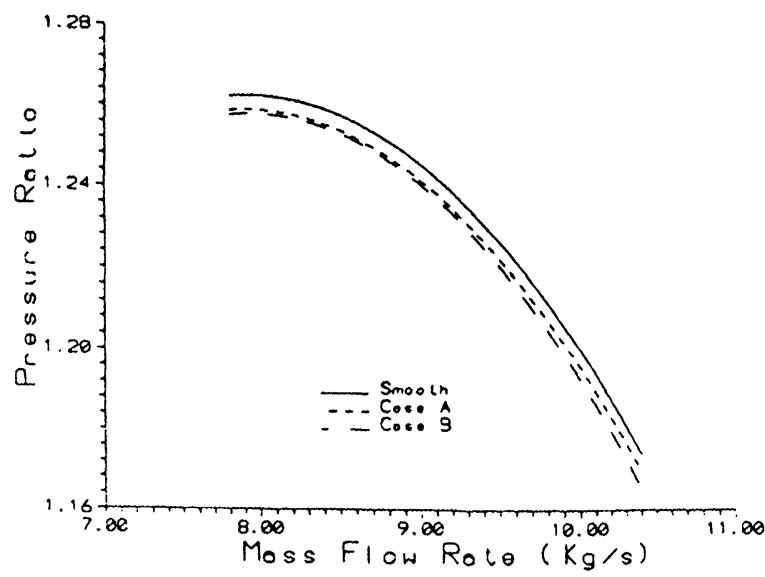

FIGURE 4 Effect of surface roughness on pressure ratio, $\mathrm{N}=100 \%$.

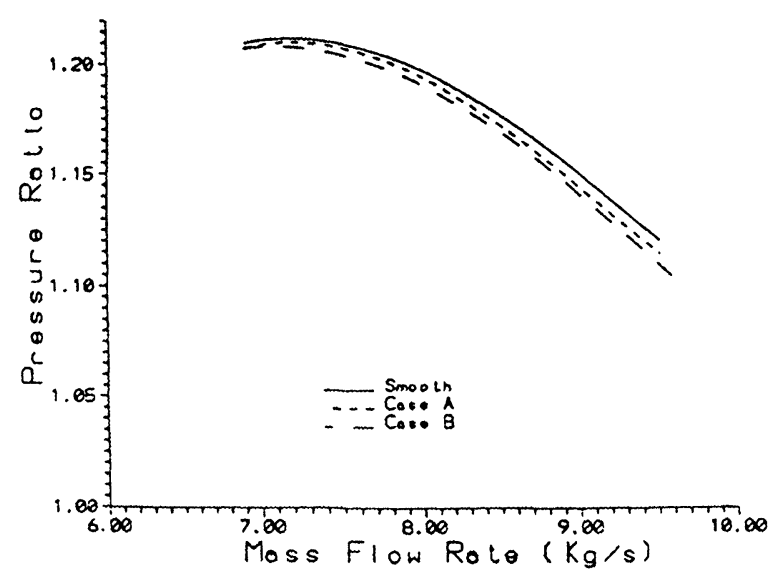

FIGURE 5 Effect of surface roughness on pressure ratio, $\mathrm{N}=90 \%$. 


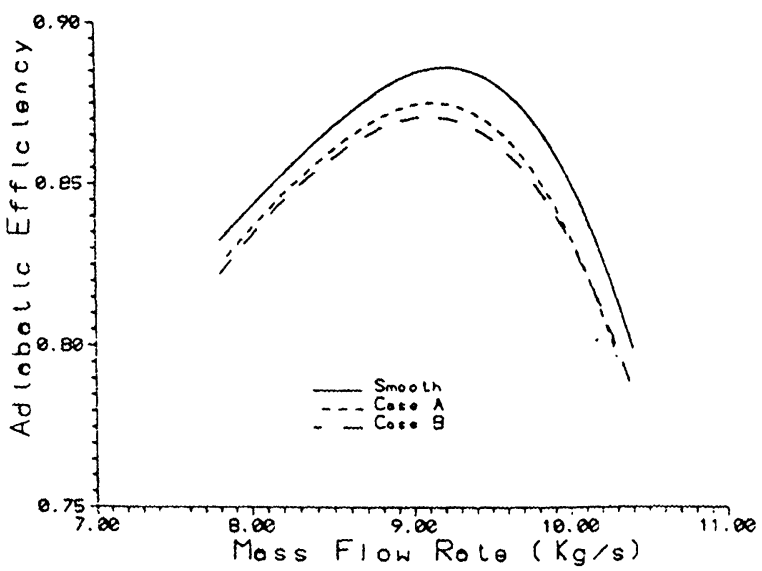

FIGURE 6 Effect of surface roughness on adiabatic efficiency, $\mathrm{N}=100 \%$.

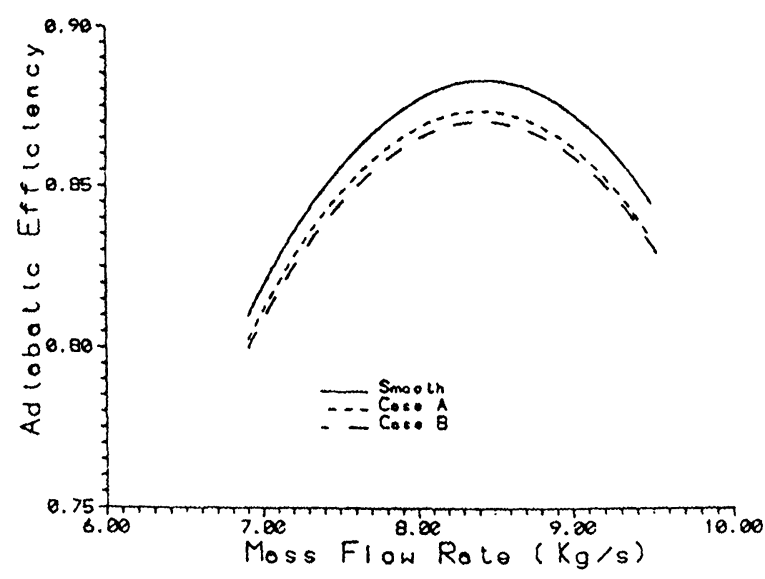

FIGURE 7 Effect of surface roughness on adiabatic efficiency, $\mathrm{N}=90 \%$.

the adiabatic efficiency compared to the pressure ratio. The drop in adiabatic efficiency, due to increased blade roughness, caused by moderate erosion (case A) is approximately $2 \%$ at both $100 \%$ and $90 \%$ speeds. The drop in the pressure ratio and adiabatic efficiency is small in going from the roughness Case A to Case B. This is in agreement with the experimental results of Balan and Tabakoff (1984).

The combined effects of increased blade tip clearance and surface roughness (case A) due to erosion, on the compressor performance at $100 \%$ speed, are presented in Figs. 8 and 9. One can observe

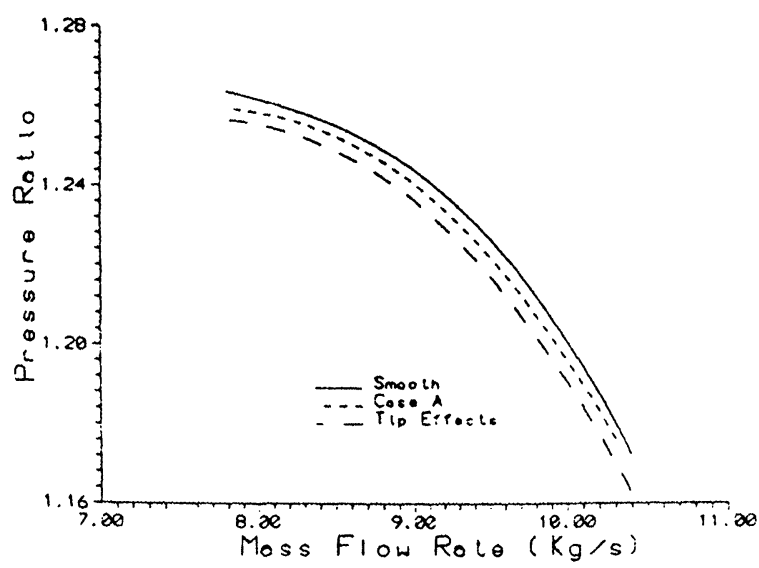

FIGURE 8 Combined effects of surface roughness and tip erosion on pressure ratio, $\mathrm{N}=100 \%$.

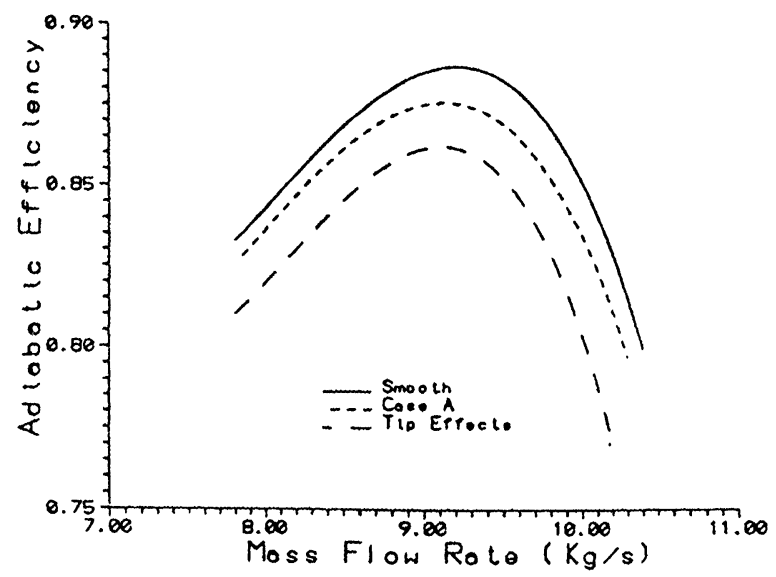

FIGURE 9 Combined effects of surface roughness and tip erosion on adiabatic efficiency, $\mathrm{N}=100 \%$.

a slight reduction in the compressor pressure ratio due to the additional effect of tip clearance. However the increased tip clearance due to erosion has a more pronounced effect on the stage adiabatic efficiency with an additional 1.5 to $2 \%$ drop over the operating range.

\section{CONCLUSIONS}

A mean line compressor performance model was developed to predict the change in compressor performance associated with blade erosion by ingested 
particles. It was validated for uneroded single stage compressor through comparison with experimental data and then applied to predict the effects of increased surface roughness and tip clearance on compressor pressure ratio and adiabatic efficiency. The model predicted a more pronounced reduction in compressor efficiency compared to the pressure ratio. A loss in adiabatic efficiency of 3-4\% was predicted under the combined effects of increased blade surface roughness and tip clearance due to erosion.

\section{NOMENCLATURE}

$\mathrm{c}=$ blade chord

$\mathrm{C}_{\mathrm{d}}=$ coefficient of drag

$\mathrm{h}=$ blade height

$\mathrm{k}_{\mathrm{s}}=$ equivalent sand grain roughness

$\mathrm{R}_{\mathrm{a}}=$ center line average roughness

$\mathrm{t}=$ tip clearance

$\beta=$ blade angles

$\varphi=$ flow coefficient

$\eta=$ efficiency

$\sigma=$ blade solidity

$\omega=$ loss coefficient

$\psi=$ work coefficient

\section{Subscripts}

$1=$ inlet

2 = outlet

$\mathrm{m}=$ mean

$\mathrm{s}=$ secondary

\section{References}

Aker, G.F. and Saravanamutto, H.I.H. (1989) Predicting Gas Turbine Performance Degradation Due to Compressor Fouling Using Computer Simulation Techniques, $A S M E$ Journal of Engineering for Power, Vol. 111, No. 2, 343-350.
Balan, C. and Tabakoff, W. (1984) Axial Flow Compressor Performance Deterioration, AIAA Paper No. 84-1208.

Balan, C. and Tabakoff, W. (1983) A Method of Predicting the Performance Deterioration of a Compressor Cascade Due to Sand Erosion, AIAA Paper No. 83-0178.

Batcho, P.F., Moller, J.C., Padova, C. and Dunn, M.G. (1987) Interpretation of Gas Turbine Response Due to Dust Ingestion, ASME Journal of Engineering for Gas Turbines and Power, Vol. 109, No. 3, 344-352.

Britsch, W.R., Osborn, W.M. and Laessig, M.R. (1979) Effects of Diffusion Factor, Aspect ratio and Solidity on Overall Performance of 14 Compressor Middle stages, NASA TP 1523.

Casey, M.V. (1987) A Mean Line Prediction Method for Estimating the Performance Characteristic of an Axial Compressor Stage, Turbomachinery Efficiency Prediction and Improvement, Institution of Mechanical Engineers Conference Proceedings, 1987-6, 273-285.

Hamed, A., Tabakoff, W. and Wenglarz, R.A. (1988) Particulate Flows and Blade Erosion, VKI Lecture Series, VKI-LS1988-08.

Horlock, J.H. (1973) Axial Flow Compressors, R.E. Krieger Publishing Company, New York.

Johnsen, I.A. and Bullock, R.O., eds. (1965) Aerodynamic Design of Axial Flow Compressors, NASA SP-36.

Koch, C.C. and Smith, L.J., Jr. (1976) Loss Sources and Magnitudes in Axial Flow Compressors, ASME Journal of Engineering for Power, Vol. 98, No. 3, 411-424.

Kramer, W.H. and Smith, J.J. (1978) Long-Term CF6 Engine Performance Deterioration-Evaluation of Engine $\mathrm{S} / \mathrm{N} 451$ 380, NASA-CR-159390.

Lakshminarayana, B. (1970) Methods of Predicting the Tip Clearance Effects in Axial Flow Turbomachinery, $A S M E$ Journal of Basic Engineering, Vol. 92, 467-482.

Miller, D.C. and Wasdell, D.L. (1987) Off-Design Prediction of Compressor Blade Losses, Turbomachinery Efficiency Prediction Improvement, Institution of Mechanical Engineers Conference Proceedings, 1987-6, 249-260.

Mills, A.F and Hang, X (1983) On the Skin Friction Coefficient for a Fully Rough Flat Plate, ASME Journal of Fluids Engineering, Vol. 105, No. 3, 364-365.

Milner, E.J. et al. (1975) Performance of a J85-13 Compressor With Clean and Distorted Inlet Flow, NASA-TM-X-3304

Muir, D.E., Saravanamutto, H.I.H and Marshall, D.J. (1989) Health Monitoring of Variable Geometry Turbines for the Canadian Navy, ASME Journal of Engineering for Gas Turbines and Power, Vol. 111, No. 2, 244-250.

Swan, W.C. (1961) A Practical Method of Predicting Transonic Compressor Performance, ASME Journal of Engineering for Power, Vol. 83, 322-330.

Tabakoff, W. (1988) Causes for Turbomachinery Performance Deterioration, ASME Paper No. 88-GT-294.

Tabakoff, W., Lakshminarasimha, A.N. and Pasin, M. (1990) Simulation of Compressor Performance Deterioration Due to Erosion, ASME Journal of Turbomachinery, Vol. 112, No. 1, $78-83$. 


\section{ait \\ ENERGY MATERIALS}

M A N E Y publishing

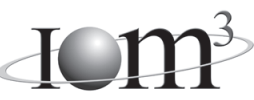

\section{Materials Science \& Engineering for Energy Systems}

Maney Publishing on behalf of the Institute of Materials, Minerals and Mining

The Institute of Materials, Minerals \& Mining

Economic and environmental factors are creating ever greater pressures for the efficient generation, transmission and use of energy. Materials developments are crucial to progress in all these areas: to innovation in design; to extending lifetime and maintenance intervals; and to successful operation in more demanding environments. Drawing together the broad community with interests in these areas, Energy Materials addresses materials needs in future energy generation, transmission, utilisation, conservation and storage. The journal covers thermal generation and gas turbines; renewable power (wind, wave, tidal, hydro, solar and geothermal); fuel cells (low and high temperature); materials issues relevant to biomass and biotechnology; nuclear power generation (fission and fusion); hydrogen generation and storage in the context of the 'hydrogen economy'; and the transmission and storage of the energy produced.

As well as publishing high-quality peer-reviewed research, Energy Materials promotes discussion of issues common to all sectors, through commissioned reviews and commentaries. The journal includes coverage of energy economics and policy, and broader social issues, since the political and legislative context influence research and investment decisions.

\section{CALL FOR PAPERS}

Contributions to the journal should be submitted online at http://ema.edmgr.com

To view the Notes for Contributors please visit: www.maney.co.uk/journals/notes/ema

Upon publication in 2006, this journal will be available via the Ingenta Connect journals service. To view free sample content online visit: www.ingentaconnect.com/content/maney

For further information please contact:

Maney Publishing UK

Tel: +44 (0)113 2497481 Fax: +44 (0)1132486983 Email: subscriptions@maney.co.uk

or

Maney Publishing North America

Tel (toll free): 8662975154 Fax: 6173546875 Email: maney@maneyusa.com

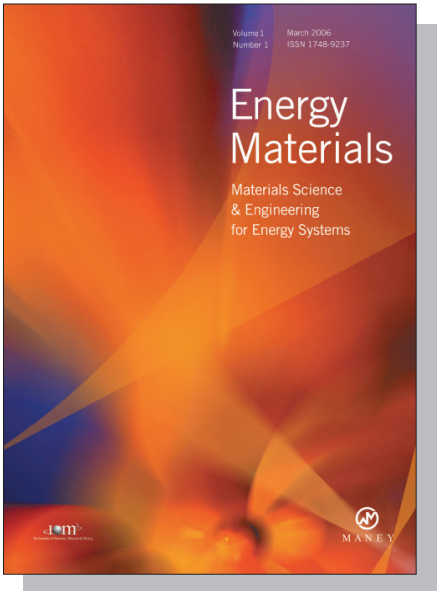

EDITORS

Dr Fujio Abe

NIMS, Japan

Dr John Hald, IPL-MPT, Technical University of Denmark, Denmark

Dr R Viswanathan, EPRI, USA

\section{SUBSCRIPTION INFORMATION}

Volume 1 (2006), 4 issues per year

Print ISSN: 1748-9237 Online ISSN: 1748-9245

Individual rate: $£ 76.00 / U S \$ 141.00$

Institutional rate: $£ 235.00 /$ US $\$ 435.00$

Online-only institutional rate: $£ 199.00 / U S \$ 367.00$

For special $\mathrm{IOM}^{3}$ member rates please email

subscriptions@maney.co.uk

\section{For further information or to subscribe online please visit www.maney.co.uk}



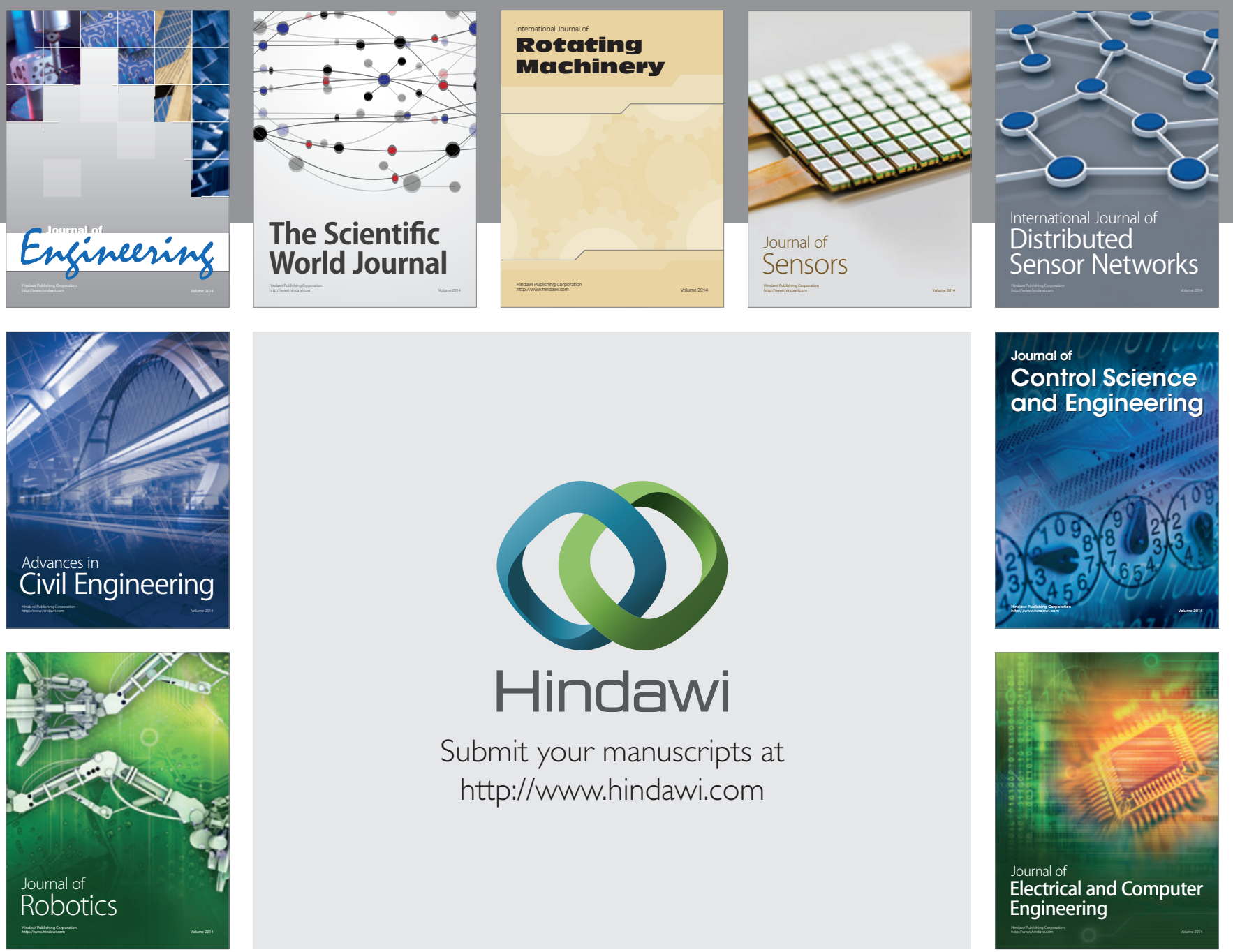

Submit your manuscripts at

http://www.hindawi.com
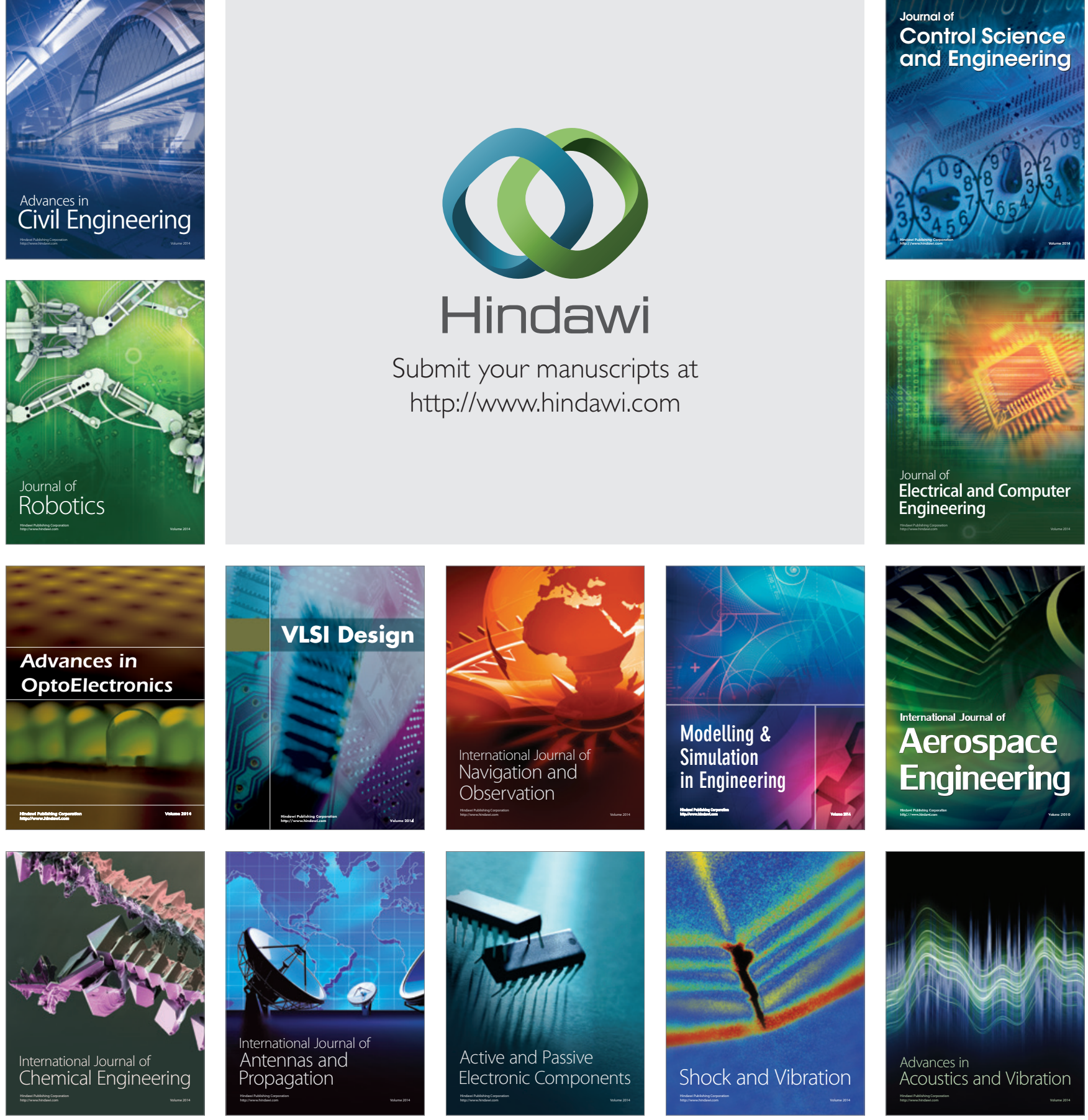